\title{
Impact of Effective Business Communication on Employee Performance
}

\author{
Stavros Kalogiannidis
}

\begin{abstract}
Communication is considered an essential tool for organizational performances and growth. Most business rely on effective communication with both customers and employees to improve sales and enhance business growth. Poor or ineffective communication normally leads to mismanagement of an organization and undesirable business results. This study sought to explore the impact of business communication on the performances of employees. Communication was conceptualized into horizontal, downward, and upward communication forms and their influence on employee performance was determined based on data from 110 participants who were employees of different banking institutions in Greece. The study confirmed that effective communication in any business entity has a great influence in employee performance. Business are encouraged to maintain a good flow of information across the organization to as to improve employee performances and business profitability in the long run.
\end{abstract}

Index Terms - Business communication, Employee performance, Horizontal communication, downward communication and upward communication.

\section{INTRODUCTION}

Communication is commonly described as a process of sending messages through different platforms and it is normally comprised of verbal or nonverbal sentiments [1]. Effective business communication is considered very important in enhancing the general performance of different business entities since it influences proper co-ordination between the employees and the employer or between the entity and its customers. Through proper business communication, business entities are able to enhance their organizational management, improve employee commitment, enhance profitability and consequently boost the overall performance of organizations. Speaking, listening and having the ability to effectively or efficiently understand both verbal and nonverbal meanings are among the most important skills that mangers must possess in order to support or maintaining effective communication in organizations which is a perquisite for both improved performance and business growth. Basic business communication skills are normally learned or developed through observing other competent people and consequently modelling individual behaviors based on what is observed on other professionals. It is important note that business information has no relevance if it is not effectively communicated across different stakeholders in an

Published on December 10, 2020.

Stavros Kalogiannidis, Adjunct Lecturer, Department of Regional and Cross Border Development, University of Western Macedonia, Greece.

(corresponding e-mail: stavroskalogiannidis ${ }^{@}$ gmail.com) organization. Communication in business entities can therefore be interpreted as the general process of disseminating or transmitting business information from one employee to another or from one business stakeholders to another. Effective communication also helps to build teamwork in the organization and consequently enhances employee performance. This also helps to reduce the rate of turnover redundancy in the organization. On the contrary weak business communication affects the general confidence of employees which has a negative impact on both the productivity of employees and performance of the business entity [2].

Organizations that are so deficient in their means of communication rarely achieve greater performance as compared to those that possess high level of effective business communication. Business scholars such as AlTokhais [1] indicated that the rationale of business communication is organizations is majorly to maintain a good relationship between the organization and its different stakeholders that cut across employees, shareholders and business partners among others. However, most of these business searchers have confirmed that the relevance of business communication on employee performance is normally ignored which forms the basis for this current study [2]. This study seeks to bridge the existing research gap in the business communication research by testing the following hypothesis:

H1: There is a significant relationship between horizontal communication and employee performance.

H2: There is a significant relationship between downward communication and employee performance.

H3: There is a significant relationship between upward communication and employee performance.

\section{LITERATURE REVIEW}

This section resents the theoretical perspective of business communication and the empirical review of the different constructs of communication as well as their impact on employee performance.

\section{A. Theoretical Review}

Most communication scholars gave continued to connect and consequently integrate business communication across different levels of analysis ranging from micro to the macro levels of organization. Albert Bandura's (1986) social cognitive theory and Jams Prochaska et al. (1994) transtheoretical model assert that the general behavior of an individual is always formed based on the perspectives of the broader community and social environment. This therefore indicates that interventions aimed at ensuring effective 
communication in an organization must always include all efforts that influence positive changes in the larger organizational environmental.

Similarly, most persuasion studies have focused on how the individual-level communication impacts the general behavior of a person. Most researchers have tried to explain the continued shifting nature of most organizations especially as they are currently formed and consequently transformed through different interactions among different groups and systems. The most important interactions leading to positive organizational change are normally conducted among members of an organization. The external environment or audiences and cultural meaning systems, among others [3].

Most early studies focused on behavioral change among employees as a result of poor communication in organization. Most of these studies indicated that behavioral change was normally influenced by several variables including credibility of the source of data or information, fear, nature of arguments, and personality differences, among many other variables.

Since the 1960's most business related studies have emphasized cognitive processing of data or information that results in persuasion. On the contrary recent studies have revealed that business and managed communication is an important and strategic tool for co-operations to achieve their desired growth in terms of profitability and performance [3].

\section{B. Empirical Review}

\section{Employee Performance}

Employee performance is commonly defined as the behavior exhibited by an employee while performing a particular task assigned by the employer. It also relates to the outcome produced by a particular employer in an organization. Fuertes et al. [4] indicates that employee performance is associated with the achievements of every employee in accordance with the different rules, regulations or expectations of the organization or employer.

According to Jiang et al. [5], the nature of employee performance reflects the abilities and capabilities of each individual employee in an organization. In this case, most competent and skirled employees tend to exhibit a high level of expertise and commitment on the job which leads to greater employee performance as compared to those with less expertise and skills. However, most scholars assert that there are additional factors that influence the level of employee performance other than skills, competence and expertise or professionalism, effective communication in an organization is among the most essential factors that influence employee performance and productivity levels. Fuertes et al. [4] assert that excellent employee performance is essential in the creation of high-quality services for customers and higher profitability for the organizations. These benefits of enhanced employee performance tend to lead to sustainable competitive advantage in the long run.

The zeal and commitment of employees is normally boosted when the other employees or managers on the organization are undertaking their jobs effectively. The nature in which the organization interacts or communicates with the employees plays a key role in improving employee performances since it acts as a source of motivation and new knowledge, or skills [5].

\section{Business Communication and Employee Performance}

According to Otoo [6], most effective leaders or mangers in are those that clearly understand the different aspects of communication and its general impact on the organization's setting or structure. Possession of knowledge on the relevance of business communication enables managers to improve the nature of communication in the organization which in the long run yields positive results most especially concerning employees' productivity performance. Odine [7] indicates that effective communication is a very reliable vehicle that helps employees to fulfill their organizational obligations. To enhance productivity in an organization, managers must be willing to promote free-flowing communication across the different departmental units in the organization.

Managers have an obligation of clearly communicating the different organizational goals and objectives to the employees and other stakeholders and this acts an inspiration or motivating factor to the employees. Jiang et al. [5] also indicate that effective communication helps to build trust between employees and the top leadership of the organization which encourages the former to perform efficiently on the job. Maintaining a desirable level of effective communication between managers and employees helps the former to successfully control and monitor progress of the different activities being undertaken by employees in the organization. Otoo [6] suggests that emphasizing a good flow of information across the entire workforce in the organization helps in achieving the different strategic goals and objectives.

Odine [7] revealed that communication is not necessarily about talking, listening, and writing but rather involves people interacting and understanding each other as well as sharing knowledge or ideas about different issues. Various studies have revealed that effective communication enables managers to share goals with other stakeholders of the organization both internally and externally.

\section{Forms of Communication}

\section{Horizontal Communication}

Horizontal communication is associated with exchange of information or ideas across the same level or departmental unit in an organization. Otoo [6] indicates that with horizontal business communication, the message is effectively transmitted along a specific or defined level in an organization hence may not move beyond that particular level. Horizontal communication helps employees to directly share essential information, actively participate in problem solving processes and collaborate to ensure successful execution of different assigned duties and responsibilities. Effective horizontal communication normally results in a higher quality of information exchange in an organization. This is based on the fact that it occurs directly between the different employees working in the same departmental or at the same level in the organization. Research indicates that most organizations rely on horizontal communication to ensure proper coordination of the different activities in the various departments of the organization. The other importance of horizontal 
communication is that it helps in the development stronger relationships among the employees. This in the long run improves the general productivity and performances of the entire employee group in an organization [8]. Hence, it was hypothesized that:

There is a significant relationship between horizontal communication and employee performance.

\section{Downward Communication}

Downward communication is associated with messages being transmitted right from superiors to the different subordinates in the organization [9]. In this case information flows from the top management to lower level employees. The transmission of messages under downward communication is done from top to bottom along the organization's hierarchy. Under this form of communication, employees are able to share knowledge and information with other different superiors at the different levels of management. Osborne \& Hammoud [8] indicate that interacting and sharing ideas with the most experienced and qualified managers or superiors motivate employees to perform better in an organization. Hence it was hypothesized that:

There is a significant relationship between downward communication and employee performance.

\section{Upward Communication}

Most business researchers have described upward communication as he mode of communication that involves transfer of information from subordinates to their managers or superiors in an organization [1], [10]. Studies indicate that under upward communication, the different essential messages and information are shared from the bottom to top along the defined hierarchy of a particular organization [7], [9]. Upward communication is normally utilized when subordinates request for different opinions or information from their superiors. Research indicates that upward communication helps to trigger different decisions from the top leadership or management of an organization. The different aspects of upward communication improve the levels of cooperation between the employees and the top management or superiors. Studies indicate that upward communication in any business entity allows employees to freely express their opinions or feelings concerning the nature of the job and other pressing issues at the workplace [11]. This has a great impact on their ability to perform efficiently on their different task or obligations. Hence it was hypothesized that:

There is a significant relationship between upward communication and employee performance.

\section{METHODS}

This section describes the methods and tools used in conducting this study

\section{A. Research Design}

The study adopted a cross-sectional survey design that involved using an online survey questionnaire to collect data from different participants selected from the different financial institutions in Greece. The study employed probability sampling techniques whereby simple random sampling technique was used in selecting the different study participants. The reason for using the different employees of financial institutions was based on the fact that they possess great knowledge con darning the relationship between business communication and employee performance.

\section{B. Sample}

Data was collected from a sample of 110 participants who were selected from the different banking institutions in Greece.

\section{Measurement of Variables}

The influence of business communication on employee performance was measured based on a Likert scale of 5 constructs (1-5) that included; Strongly disagree (1), disagree (2), Not sure (3), Agree (4) and Strongly agree (5).

\section{Data Collection and Analysis}

Data collection was conducted by availing the survey questionnaire through an online data collection platform (Survey monkey) that involved engaging with the targeted sample size of participants. The questionnaire was completed by the respondents in a period of about 10 minutes. Statistical Package for Social Sciences (SPSS) software was used to analyze the data obtained. Regression analysis was also undertaken in order to determine the level to which the different forms of communication predict the level of employee performance in an organization. In this case a multiple regression model was of great importance in estimating different predictive values.

$$
Y=\beta_{O}+\beta_{1} X_{1}+\beta_{2} X_{2}+\beta_{3} X_{3}+\varepsilon
$$

where

$\mathrm{Y}=$ Employee performance.

$\beta 0=$ constant (coefficient of intercept).

$X_{1}=$ Horizontal communication.

$X_{2}=$ Downward communication

$X_{3}=$ Upward communication.

$\varepsilon=$ Represents the error term in the multiple regression model.

$\beta 1 \ldots \beta 3=$ Represents the regression coefficient of the different independent variables of the study which double as the different constricts or forms of communication that are normally used in organizations and these helped in determining the level of influence that the independent variables (Horizontal communication, Downward communication, and Upward communication) on the dependent variable (Employee performance).

\section{RESUlTs}

\section{A. Background Information}

Out of the 110 participants, $73(66.4 \%)$ were males whereas $27(33.6 \%)$ were female. Majority of the study particulates were aged between 25 to 36 years and this represented $62 \%$ of the total number of participants. Concerning marital status, the results showed that only $46 \%$ of the participants were married while the least portion of participants $(5 \%)$ were divorced. Concerning education background, majority of the participants $(98,89.1 \%)$ were bachelor's degree holders. 


\section{B. Descriptive Analysis}

\section{Analysis of Employee Performance}

The results in Table 1 show that 5 variables had means above 3.5 which clearly indicated the existence of the different variables about upward communication. This shows that participants agreed or strongly agreed to all these statements about employee performance. However, employees disagreed with two statements which included: I am always recognized for quality work done (2.54) and I am given feedback concerning the quality of my work (3.27). Such scenarios in organizations tend to affect the level of employee performance.

\section{Analysis of Horizontal Communication and Employee Performance}

The study focused on assessing horizontal communication based on opinions of participants as presented in Table 2 below. The means in Table 2 were all above 3.5 which clearly indicated the existence of the different variables about upward communication. This shows that participants agreed or strongly agreed to all the statements about horizontal communication. The relationship between horizontal communication and employee performance is presented in Table 3.

The results confirmed a significant relationship between horizontal communication and employees' performance $\left(\mathrm{r}=0.316^{* *}, \mathrm{n}=110, \mathrm{p}=.000\right)$. We accept $\mathrm{H} 1$; that there is a significant relationship between horizontal communication and employees' performance.

3. Analysis of Downward Communication and Employee Performance

The analysis of the different opinions of participants concerning downward communication is presented in Table 4 below.

The means in Table 4 were all above 3.5 which clearly indicated the existence of the different variables about upward communication. This shows that participants agreed or strongly agreed to all the statements about downward communication. The relationship between downward communication and employee performance is presented in Table 5.

The results showed that there is a positive relationship between downward communication and employees' performance $\left(\mathrm{r}=0.531^{* *}, \mathrm{n}=110, \mathrm{p}=.000\right)$. This was an indication that the different aspects of downward flow of information tend to boost employees' performance in an organization. These results also led to the acceptance of the null hypothesis $\mathrm{H}_{2}$; that there is a significant relationship between downward communication and employee performance.

TABLE 1: DESCRIPTIVE STATISTICS ON EMPLOYEE PERFORMANCE

\begin{tabular}{lccccccc}
\hline \multicolumn{1}{c}{ Items } & \multicolumn{4}{c}{ Percentage responses (\%) } & Mean & $\begin{array}{c}\text { Std. } \\
\text { Deviation }\end{array}$ \\
\cline { 2 - 7 } & 1 & 2 & 3 & 4 & 5 & & .107 \\
\hline I am always recognized for quality work done & $13 \%$ & $15.7 \%$ & $3.9 \%$ & $39.4 \%$ & $19.7 \%$ & 2.54 & .588 \\
I am given feedback concerning the quality of my work & $9.2 \%$ & $10.5 \%$ & $11.8 \%$ & $43.4 \%$ & $25 \%$ & 3.27 & .506 \\
$\begin{array}{l}\text { My manager always briefs in my contribution to the } \\
\text { organization }\end{array}$ & $2.1 \%$ & $21 \%$ & $6.5 \%$ & $38 \%$ & $13 \%$ & 3.70 & .50 \\
$\begin{array}{l}\text { I always base on advice from colleagues to perform } \\
\text { better }\end{array}$ & $1.5 \%$ & $6.5 \%$ & $7.8 \%$ & $55 \%$ & $28.9 \%$ & 4.01 & .483 \\
$\begin{array}{l}\text { I continuously seek more knowledge and skills to } \\
\text { perform better on my job }\end{array}$ & $3.9 \%$ & $3.9 \%$ & $7.8 \%$ & $52.6 \%$ & $31.5 \%$ & 4.12 & .464 \\
$\begin{array}{l}\text { I am always eager to explore new ideas about my job so } \\
\text { as to perform better }\end{array}$ & $2.6 \%$ & $2.6 \%$ & $6.5 \%$ & $53.9 \%$ & $34.2 \%$ & 4.14 & .433 \\
$\begin{array}{l}\text { Easy access to information has improved my desire and } \\
\text { zeal to perform better }\end{array}$ & $0 \%$ & $5.2 \%$ & $16.6 \%$ & $44 \%$ & $33.1 \%$ & 3.62 & .476 \\
\hline
\end{tabular}

Source: Primary data (2020)

TABLE 2: DeSCRIPTIVE STATISTICS ON HORIZONTAL COMMUNICATION

\begin{tabular}{|c|c|c|c|c|c|c|c|}
\hline \multirow{2}{*}{ Items } & \multicolumn{5}{|c|}{ Percentage responses $(\%)$} & \multirow{2}{*}{ Mean } & \multirow{2}{*}{$\begin{array}{c}\text { Std. } \\
\text { Deviation }\end{array}$} \\
\hline & 1 & 2 & 3 & 4 & 5 & & \\
\hline $\begin{array}{l}\text { I maintain good language when interacting with fellow } \\
\text { employees }\end{array}$ & $2.3 \%$ & $1.3 \%$ & $3.9 \%$ & $61.8 \%$ & $31.5 \%$ & 4.03 & 1.604 \\
\hline $\begin{array}{l}\text { I normally share knowledge with my colleagues on } \\
\text { essential issues }\end{array}$ & $0 \%$ & $3.9 \%$ & $9.2 \%$ & $61.8 \%$ & $25 \%$ & 4.09 & 1.282 \\
\hline $\begin{array}{l}\text { I perform better by discussing with my colleagues on the } \\
\text { job requirements }\end{array}$ & $3.9 \%$ & $2.6 \%$ & $6.5 \%$ & $53.9 \%$ & $34.2 \%$ & 4.11 & 1.195 \\
\hline I always listen to the advice from my fellow employees & $2.0 \%$ & $5.5 \%$ & $25.0 \%$ & $36.5 \%$ & $30 \%$ & 4.01 & 2.316 \\
\hline $\begin{array}{l}\text { I always seek essential information from my colleagues } \\
\text { in my department }\end{array}$ & $5.2 \%$ & $5.2 \%$ & $11.8 \%$ & $42 \%$ & $35.5 \%$ & 4.18 & 1.506 \\
\hline $\begin{array}{l}\text { Sharing information keeps employees motivated to } \\
\text { perform better }\end{array}$ & $2.6 \%$ & $3.9 \%$ & $7.8 \%$ & $59 \%$ & $26.3 \%$ & 4.21 & 1.926 \\
\hline
\end{tabular}

Source: Primary data (2020).

TABLE 3: CORRELATION BETWEEN HORIZONTAL COMMUNICATION AND EMPLOYEE PERFORMANCE

\begin{tabular}{|c|c|c|c|}
\hline & & $\begin{array}{c}\text { Horizontal } \\
\text { communication }\end{array}$ & $\begin{array}{c}\text { Employee } \\
\text { performance }\end{array}$ \\
\hline \multirow{3}{*}{$\begin{array}{c}\text { Horizontal } \\
\text { communication }\end{array}$} & Pearson & 1 & $.316^{* *}$ \\
\hline & Correlation & & .000 \\
\hline & $\begin{array}{l}\text { Sig. (2-tailed) } \\
\mathrm{N}\end{array}$ & 110 & 110 \\
\hline \multirow{3}{*}{$\begin{array}{c}\text { Employee } \\
\text { performance }\end{array}$} & Pearson & $.316^{* *}$ & 1 \\
\hline & Correlation & .000 & \\
\hline & $\begin{array}{l}\text { Sig. (2-tailed) } \\
\mathrm{N}\end{array}$ & 110 & 110 \\
\hline
\end{tabular}


TABLE 4: DESCRIPTIVE STATISTICS ON DOWNWARD COMMUNICATION

\begin{tabular}{|c|c|c|c|c|c|c|c|}
\hline & \multicolumn{5}{|c|}{ Percentage responses $(\%)$} & \multirow{2}{*}{ Mean } & \multirow{2}{*}{$\begin{array}{c}\text { Std. } \\
\text { Deviation }\end{array}$} \\
\hline & 1 & 2 & 3 & 4 & 5 & & \\
\hline $\begin{array}{l}\text { Easy flow of information from my superior improves } \\
\text { my job performance }\end{array}$ & $5.2 \%$ & $11.8 \%$ & $5.2 \%$ & $42 \%$ & $35.5 \%$ & 3.73 & .610 \\
\hline My views and ideas are given attention by my manager & $1.3 \%$ & $1.3 \%$ & $3.9 \%$ & $71.8 \%$ & $21.5 \%$ & 4.17 & .597 \\
\hline $\begin{array}{l}\text { I derive motivation from communicating with the top } \\
\text { management team }\end{array}$ & $0 \%$ & $0 \%$ & $7.8 \%$ & $50 \%$ & $42.2 \%$ & 4.51 & .640 \\
\hline $\begin{array}{l}\text { I have knowledge on the nature of my tasks as provide } \\
\text { by my manager }\end{array}$ & $0 \%$ & $0 \%$ & $2.6 \%$ & $50 \%$ & $47.3 \%$ & 4.37 & .639 \\
\hline $\begin{array}{l}\text { My manager ensures that I have a continued access to } \\
\text { essential information }\end{array}$ & $14.4 \%$ & $9.2 \%$ & $36.8 \%$ & $28.9 \%$ & $7.8 \%$ & 4.44 & .467 \\
\hline I access essential information from my manager & $5.2 \%$ & $11.8 \%$ & $5.2 \%$ & $42 \%$ & $35.5 \%$ & 3.83 & .131 \\
\hline
\end{tabular}
Source: Primary data (2020).

TABLE 5: CORRELATION BETWEEN DEMOCRATIC MANAGEMENT STYLE AND EMPLOYEES PERFORMANCE

\begin{tabular}{clcc}
\multicolumn{4}{c}{ AND EMPLOYEES PERFORMANCE } \\
\hline & $\begin{array}{c}\text { Downward } \\
\text { communication }\end{array}$ & $\begin{array}{c}\text { Employee } \\
\text { performance }\end{array}$ \\
\hline \multirow{2}{*}{$\begin{array}{c}\text { Downward } \\
\text { communication }\end{array}$} & Pearson & 1 & $.531^{* *}$ \\
& Sig. (2-tailed) & 110 & .00 \\
& $\mathrm{~N}$ & $.531^{* *}$ & 110 \\
Employee & Pearson & .000 & 1 \\
performance & Sig. (2-tailed) & 110 & 110 \\
& $\mathrm{~N}$ & & \\
\hline
\end{tabular}

**. Correlation is significant at the 0.01 level (2-tailed).

Source: Primary Data (2020).

\section{Analysis of Upward Communication}

The analysis of the different opinions of participants concerning upward communication is presented below.

The means in Table 6 were all above 3.5 which clearly indicated the existence of the different variables about upward communication. This shows that participants agreed or strongly agreed to all the statements about upward communication. The relationship between upward communication and employee performance is presented in Table 7.

The results obtained after cross tabulation indicate that there is a positive correlation between upward communication and employee performance $\left(\mathrm{r}=0.612^{* *}\right.$, $\mathrm{n}=110, \mathrm{p}=.000)$. These led to the acceptance of the null hypothesis H3; that there is a significant relationship between upward communication and employee performance.

\section{Regression Analysis}

Regression analysis was also conducted to further establish the level to which the different independent variables (different forms of communication) predict employee performance in an organization.

The results presented in Table 8 clearly show that the different study variables can predict a $42.1 \%$ change in employee performance (Adjusted R Square $=.421$ ). The results indicated that among the different predictors of employee performance, downward communication $($ Beta $=$ $.451, \mathrm{p}<.01)$ is a better predictor as compared to horizontal communication (Beta $=.354, \mathrm{p}<.01)$ and upward communication $($ Beta $=.158, \mathrm{p}<.01)$. The results clearly show that whereas business communication being a determinant of employee performance, there are other factors that may impact employee performance other than the different components or forms of communication.

TABLE 6: DESCRIPTIVE STATISTICS ON UPWARD COMMUNICATION

\begin{tabular}{|c|c|c|c|c|c|c|c|}
\hline \multirow{2}{*}{ Items } & \multicolumn{5}{|c|}{ Percentage responses $(\%)$} & \multirow{2}{*}{ Mean } & \multirow{2}{*}{$\begin{array}{c}\text { Std. } \\
\text { Deviation }\end{array}$} \\
\hline & 1 & 2 & 3 & 4 & 5 & & \\
\hline $\begin{array}{l}\text { I provide quick feedback to my superior } \\
\text { concerning any request fir particular explanations }\end{array}$ & $10.5 \%$ & $14.4 \%$ & $30.2 \%$ & $26.3 \%$ & $18.4 \%$ & 3.68 & 1.331 \\
\hline $\begin{array}{l}\text { I request information from my manager about } \\
\text { different work issues }\end{array}$ & $7.8 \%$ & $17.1 \%$ & $28.9 \%$ & $27.6 \%$ & $18.4 \%$ & 3.33 & 1.141 \\
\hline $\begin{array}{l}\text { Top management makes decisions based our } \\
\text { request fir particular information }\end{array}$ & $10.5 \%$ & $13 \%$ & $31.5 \%$ & $22.3 \%$ & $22.3 \%$ & 3.52 & 1.133 \\
\hline $\begin{array}{l}\text { Attending to my needs on time improves my } \\
\text { performance }\end{array}$ & $13 \%$ & $15.7 \%$ & $3.9 \%$ & $39.4 \%$ & $19.7 \%$ & 2.54 & 1.107 \\
\hline $\begin{array}{l}\text { I am always appreciated for offering certain } \\
\text { information }\end{array}$ & $9.2 \%$ & $10.5 \%$ & $11.8 \%$ & $43.4 \%$ & $25 \%$ & 3.27 & .588 \\
\hline I raise any queries about the nature if the job & $21 \%$ & $21 \%$ & $6.5 \%$ & $38 \%$ & $13 \%$ & 3.70 & .506 \\
\hline $\begin{array}{l}\text { I discuss with my superiors on what to change in } \\
\text { the organization }\end{array}$ & $6.5 \%$ & $6.5 \%$ & $7.8 \%$ & $50 \%$ & $28.9 \%$ & 4.01 & .483 \\
\hline $\begin{array}{l}\text { Superiors encourage us to work better through } \\
\text { upward communication }\end{array}$ & $3.9 \%$ & $3.9 \%$ & $7.8 \%$ & $52.6 \%$ & $31.5 \%$ & 4.12 & .464 \\
\hline
\end{tabular}

Source: Primary data (2020).

TABLE 7: CORRELATION BETWEEN AUTOCRATIC UPWARD COMMUNICATION AND EMPLOYEES’ PERFORMANCE

\begin{tabular}{cccc}
\hline & Pearson & $\begin{array}{c}\text { Upward } \\
\text { communication }\end{array}$ & $\begin{array}{c}\text { Employee } \\
\text { performance }\end{array}$ \\
\hline Upward & Correlation & 1 & $.612^{* *}$ \\
communication & Sig. (2-tailed) & 110 & .000 \\
& $\mathrm{~N}$ & $.612^{* *}$ & 110 \\
Employee & Pearson & .000 & 1 \\
performance & Correlation & 110 & 110 \\
& Sig. (2-tailed) & $\mathrm{N}$ & \\
**. Correlation is significant at the 0.01 level (2-tailed). Source: Primary Data (2020).
\end{tabular}




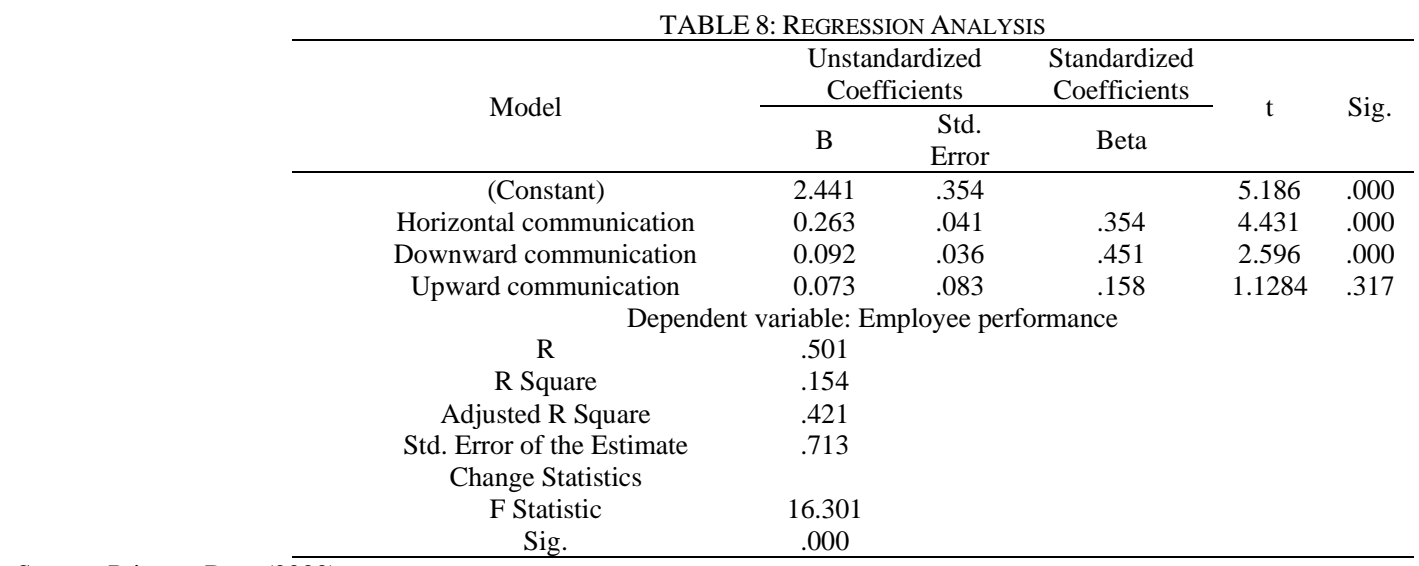

Source: Primary Data $(2020)$.

\section{DISCUSSION}

The results clearly indicate that business communication has a significant impact on the level of employee performance in an organization. The findings confirm that emphasizing effective communication in an organization helps employees to share information, ideas or knowledge and skills which enable them to effectively perform to the expectations of the employer. A positive and significant relationship between downward communication and employee performance was confirmed. The literature also revealed that effective downward communication enhances the level of leadership based communication majorly through routine updates about the operations of an organization [1], [10]. Sharing of knowledge and information between superiors or managers and employees reduce uncertainties about the top management [7]. This further helps employees to clearly understand the different reasons for the decisions undertaken by the top management. The study confirms that upward communication gives employees an opportunity to discuss their grievances or careers and other pressing issues with other superiors which helps to motivate employees towards being committed in the job. This agrees with findings of AlTokhais [1] who indicated that interactions between superiors and their subordinates, helps to solve the different problems affecting the commitment of employees on their jobs. Businesses rely on communication as the best mechanism or channel for enhancing interactions between the employees and customers or clients which greatly influences employees' performance and improves the level of business profitability in the long run [10].

\section{CONCLUSION AND RECOMMENDATIONS}

The study confirms the impact of business communication on the general performance of employees on an organization ore business entity. The different components of communication most particularly, horizontal communication, upward communication and downward communication render a great influence on the level of employee commitment on the job. This therefore indicates that the different forms communication has a great impact on employee performance and organization growth in the long run. Appropriate business communication is a very essential tool for attaining greater performance and consequently maintaining desirable working relationships in an organization. The general trust among employees can build up in an organization if every person is committed to engage in effective communication. It is important to note that clear or effective business communication helps to enhance the productivity and cooperation between employees thereby encouraging teamwork on which employees base to improve their performance. Business are encouraged to maintain a good flow of information across the organization to as to improve employee performances and business profitability in the long run.

\section{REFERENCES}

[1] Al-Tokhais, A. (2016). The relationship between communication effectiveness and multicultural employees' job outcomes (Doctoral dissertation, Kent State University).

[2] Bernstein, E. S. (2017). Making transparency transparent: The evolution of observation in management theory. Academy of Management Annals, 11(1), 217-266.

[3] Ebrahimi, R., Chamanzamin, M. R., \& Sourati, P. (2014) Investigating the effect of organizational communications on the performance of managers in government agencies of astara. International Review of Management and Business Research, 3(4), 2095.

[4] Fuertes, G., Alfaro, M., Vargas, M., Gutierrez, S., Ternero, R., \& Sabattin, J. (2020). Conceptual Framework for the Strategic Management: A Literature Review-Descriptive. Journal of Engineering, 2020.

[5] Jiang, X., Du, J., Zhou, J., \& Cui, Y. (2020). The Impact of Negative Informal Information Before a Change on Performance: A WithinPerson Approach. International Journal of Environmental Research and Public Health, 17(2), 670.

[6] Otoo, F. (2016). Effect of communication on employee performance at Ghana Revenue Authority, Kumasi (Doctoral dissertation).

[7] Odine, M. (2015). Communication problems in management. Journal of emerging issues in economics, finance and banking (JEIEFB), 4(2), 1615-1630.

[8] Osborne, S., \& Hammoud, M. S. (2017). Effective employee engagement in the workplace. International Journal of Applied Management and Technology, 16(1), 4.

[9] Rukmana, H. D., MM, S. M. P., \& SE, E. N. (2018). The Impact of Organization Communication on Employee Performance Through Employee's Work Motivation at Pt. Putri Panda Unit Ii Tulungagung, East Jawa, Indonesia. KnE Social Sciences, 211-227.

[10] Wang, Y. (2011). The Role of Communication in Enhancing Employees' Organizational Commitment: Exploring the Relationship between Social-emotional-oriented Communication, Work-oriented Communication and Organizational Commitment in China.

[11] Tian, H., Shuja Iqbal, S. A., Qalati, S. A., Anwar, F., \& Khan, M. A. S. (2020). The Impact of Transformational Leadership on Employee Retention: Mediation and Moderation Through Organizational Citizenship Behavior and Communication. Frontiers in Psychology, 11. 